\title{
Effect of Sphagneticola Trilobata Extract on Histological Wistar Rat Kidney Induced by DMBA
}

\author{
Bima Juanda Surbakti, Vivi Mardina*, Beni Al Fajar \\ Department of Biology, Faculty of Engineering, Universitas Samudra, Langsa, Indonesia \\ *Corresponding author E-mail: vmardina@unsam.ac.id
}

\begin{abstract}
One factor can trigger the growth and development of cancer cells is free radicals that are from carcinogenic compounds such as dimethylbenz $(\alpha)$ anthracene (DMBA). The use of plant extracts as a preventive or curative in cases of tumors/cancer has been reported, however there is no reports about the in vivo study for Sphagneticola trilobata plant. S. trilobata is an herbal plant that has pharmacological activities, potential to be developed as anticancer agent. This study aims to examine the anticancer effect of the methanol extract of $S$. trilobata leaves using histology observation on Wistar rat (Rattus novergicus) kidney which was induced by 7,12 dimethylbenz $[\alpha]$ anthracene (DMBA). The study used a completely randomized design with female rats (15 rats) grouped into 5 treatment groups, namely (i) the normal treatment group (KN), (ii) the DMBA-only treatment group (negative control, $\mathrm{K}(-)$ ), (iii) the first dose $(200 \mathrm{mg} / \mathrm{kg} \mathrm{BW})$ treatment group (KI), (iv) the second dose (300 mg / kg BW) treatment group (KII), and (v) the third dose (400 $\mathrm{mg} / \mathrm{kg} \mathrm{BW}$ ) treatment group (KIII). DMBA was given orally at a concentration of $18 \mathrm{mg} / \mathrm{kg} \mathrm{BW}$ for 4 times then continued for the extract. The results showed that cell damages (degeneration, necrosis and inflammation) were found mostly in negative controls. The dosage of $200 \mathrm{mg} / \mathrm{kg} \mathrm{BW}$ of $S$. trilobata extract was the optimum dose in this study which was able to inhibit histological damage of kidney organs exposed to carcinogens DMBA by decreasing the level of degeneration, necrosis and inflammation.
\end{abstract}

Keywords : DMBA, anticancer, Sphagneticola trilobata extract, degeneration, necrosis, inflamasi, histology

\section{Introduction}

The main cause of cancer is not known with certainty; however one of the factors that may trigger the growth and development of cancer cells is free radicals. Free radicals can be induced from several carcinogenic compounds such as benzo pyrene and dimethylbenz $(\alpha)$ anthracene (DMBA). Benzo $(\alpha)$ pyrene and DMBA can easily insert into deoxyribonucleic acid (DNA), causing genetic mutations that trigger the growth of cancer cells [1] [2]. The discovery of new anticancer agent by exploring natural ingredients has the potential to be developed, particularly in the use of herbal medicines. Previous studies have shown certain compounds in plants can inhibit or even kill cancer cells so that they have the potential as an anticancer agent [3] [4] [5]. One of the plant that has the potential as an anticancer is Sphagneticola trilobata [6] [7]. [3] states that the methanol extract of Sphagneticola trilobata leaves contains bioactive steroid compounds that have cytotoxic activity against in vitro cancer cell. As far as literature review on S. trilobata, there is no scientific data on the use of Sphagneticola trilobata as an anti-tumor / anti-cancer agent in vivo in view of histological preparat of renal mammals. Thus, this study aimed to investigate the potential of S. trilobata leaves as an anticancer agent in vivo in view from histological description of renal mammal (Rattus novergicus) that induced by 7,12 dimethylbenz $[\alpha]$ anthracene (DMBA).

\section{Methods}

The main material (leaves of S. trilobata) was collected from Langsa, Aceh. Rattus novergicus was obtained from Roemah Mencit Medan, Indonesia, and compound DMBA was purchased from Sigma Alderich Singapore. The research was performed at the Universitas Samudra. However, the histological preparat of renal was made at the anatomical pathology laboratory, faculty of medicine, Universitas Sumatera Utara.

The S. trilobata extract was prepare using the method which suggested by [2]. Briefly, leaves samples were dried for $\pm 7-10$ days and cut into small pieces before soaking in methanol for 3 days. Preparation of DMBA Carcinogen Suspension was dissolved in olive oil with a concentration of $18 \mathrm{mg} / \mathrm{kg} \mathrm{BW}$ of animals.

The animals used in this study were 15 female white rats of the Rattus Norvegicus type, body weight \pm 160 grams, aged 5-6 months. The animals were divided into 5 groups, each consisting of 3 animals. DMBA induction was carried out at a concentration of $18 \mathrm{mg} / \mathrm{kg}$ BW of 
test animals [8] and continued with the provision of methanol extract of $S$. trilobata leaves. The dose given was below the LD 50 value according to the research of [9]. The treatments in this study were grouped into (i) rats in the normal treatment group (KN), (ii) rats in the DMBA treatment group only (negative control, K (-)), (iii) rats in the first treatment group (200 $\mathrm{mg} / \mathrm{kg} \mathrm{BW}) \mathrm{KI}$, (iv) rats in the treatment group dose II (300 mg / kg BW) K-II, and (v) rats in the treatment group dose III (400 mg/kg BW) K-III.

Histological preparats were made using the fixation method. The specimens were cut in a representative manner and then immediately fixed with $10 \%$ formalin for 3 hours, washed under running water 3-5 times for 15 minutes. Then proceed with the triming and dehydration process by alcohol with a level of $70 \%, 80 \%, 90 \%$, and $100 \%$, each for 1 to 2 hours. Furthermore, the specimens were soak with toluene for 1 to 2 hours and xylol immersion. The last stage was paraffin embedding process before staining process in hematoxylin. Furthermore, tissue closure is carried out by giving sufficient entellent (adhesive) to the object glass and covered with a cover glass. The respons in this study were analyzed by one way ANOVA (Software SPSS, 25).

\section{Results and Discussion}

The change in body weight of $R$. novergicus during treatment is shown in figure 1 . In general, the body weight of $R$. novergicus for the normal control group $(\mathrm{KN})$ showed a higher body weight compared to the treatment group.

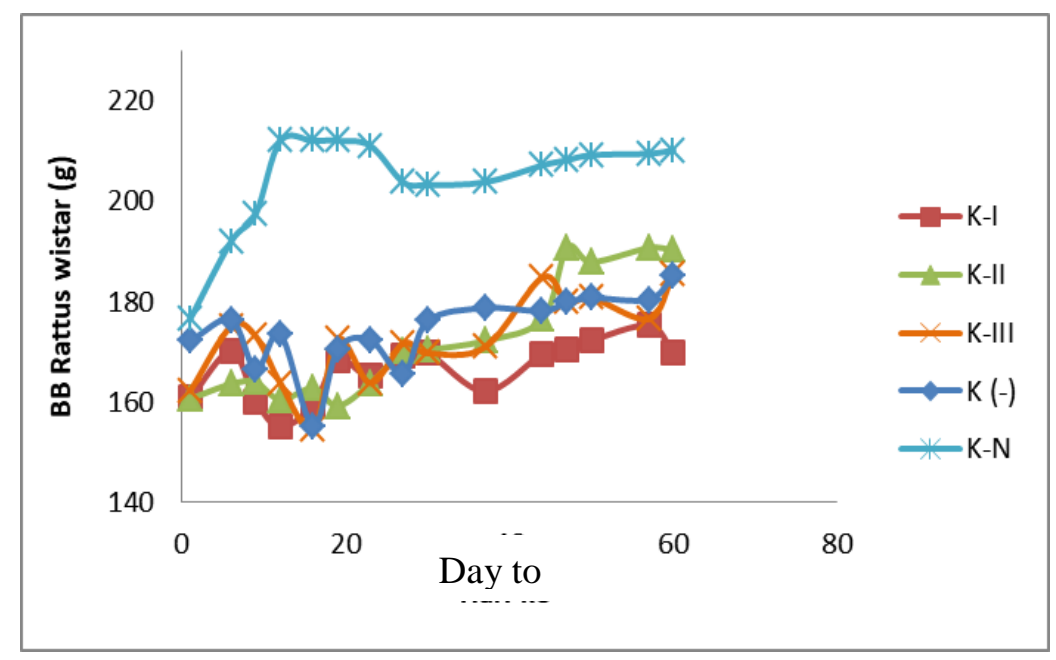

Fig 1. The average of $R$. novergicus body weight during 60 days treatment

The histological changes of $R$. novergicus kidney during treatment are shown in Figure 2. The degenerative damage, necrosis, and inflammation are shown in figure 2 .

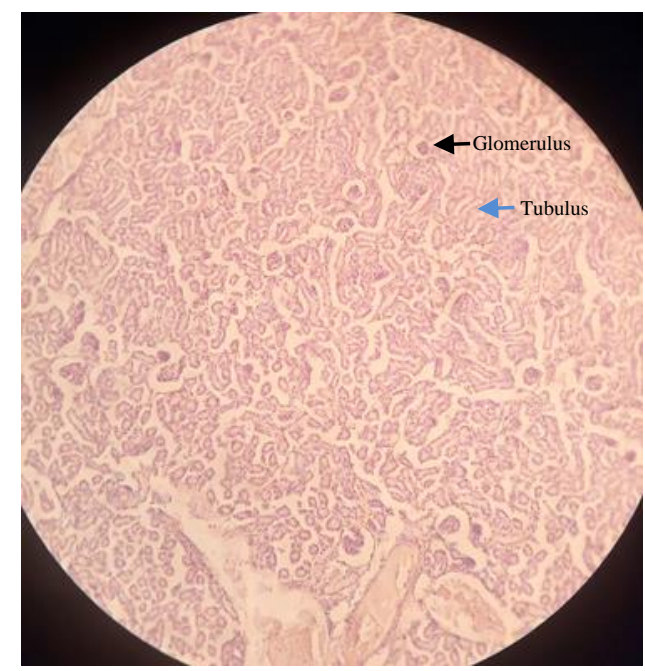

A. KN group without treatment. 10x magnification (HE).

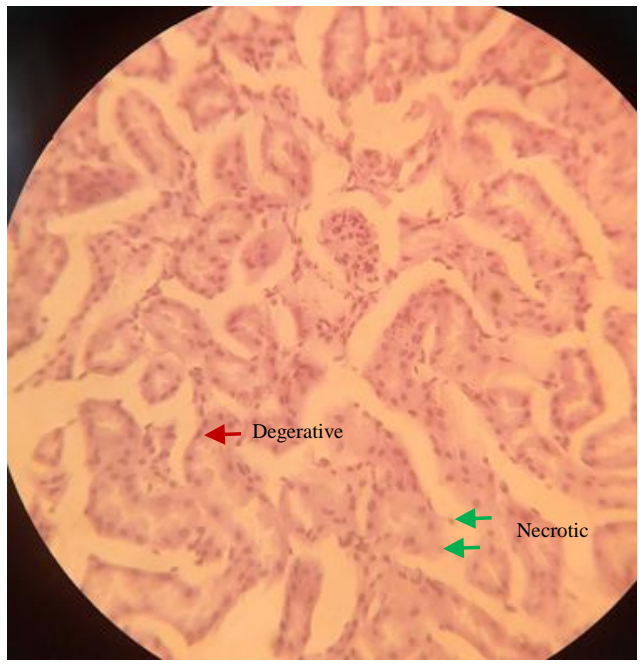

B. KN group without treatment. 40x (HE) magnification. a. Necrosis, b. Degeneration 


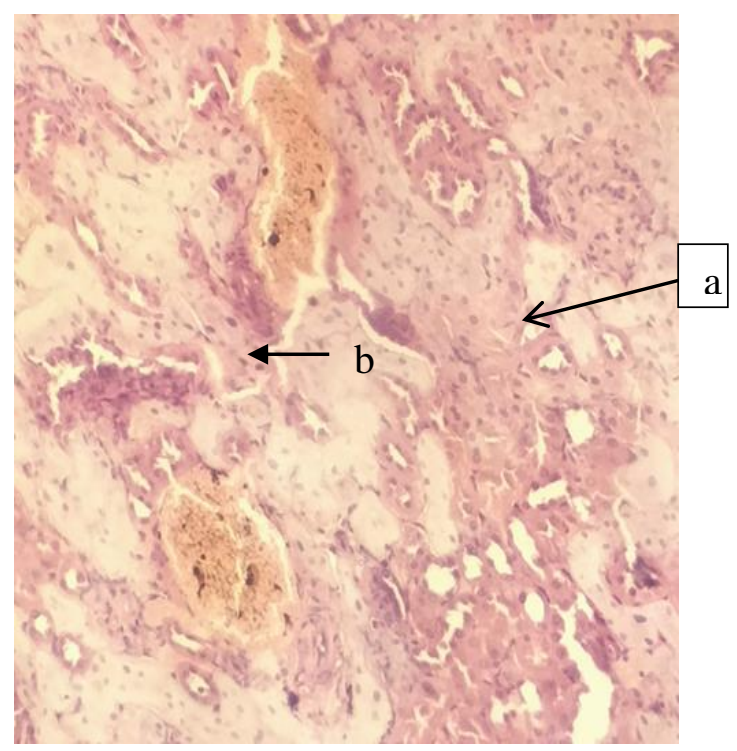

C. Control (-) DMBA treatment (K (-)). 10x magnification (HE).

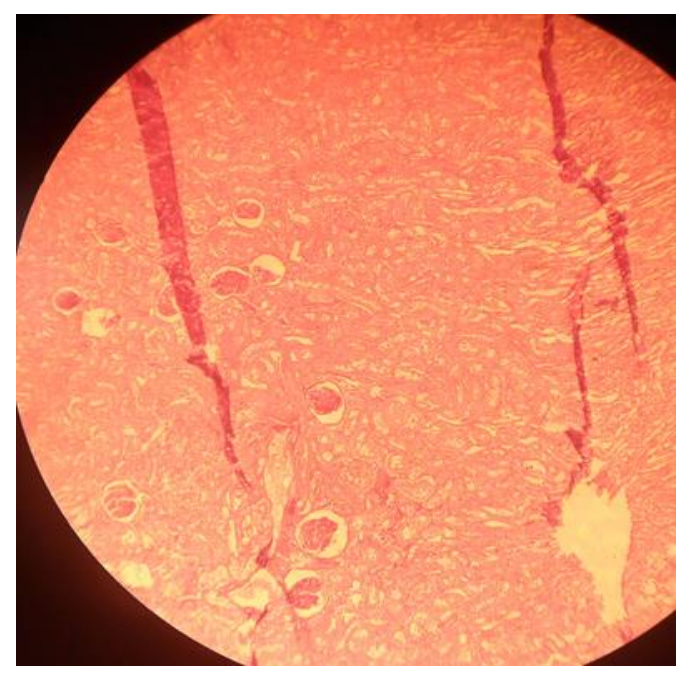

E. Treatment I (K-I) (200mg / kg BW). 10x magnification (HE)

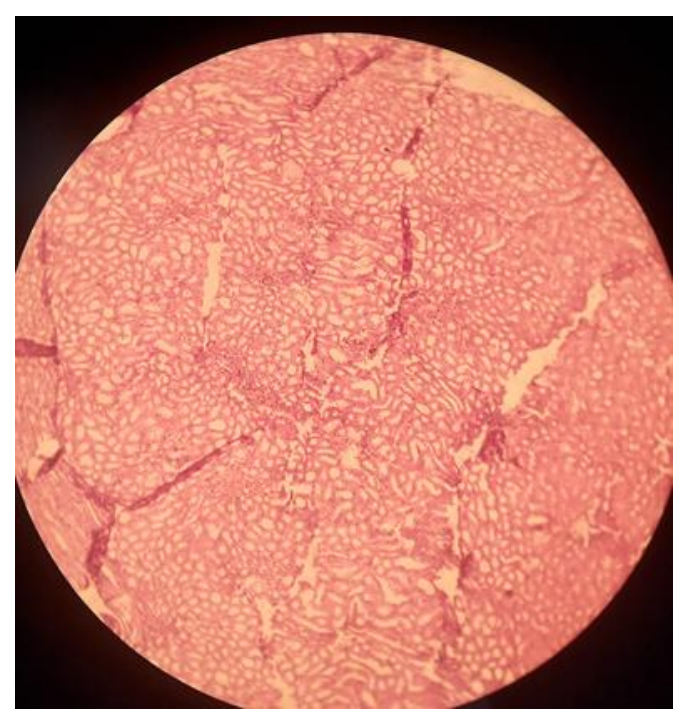

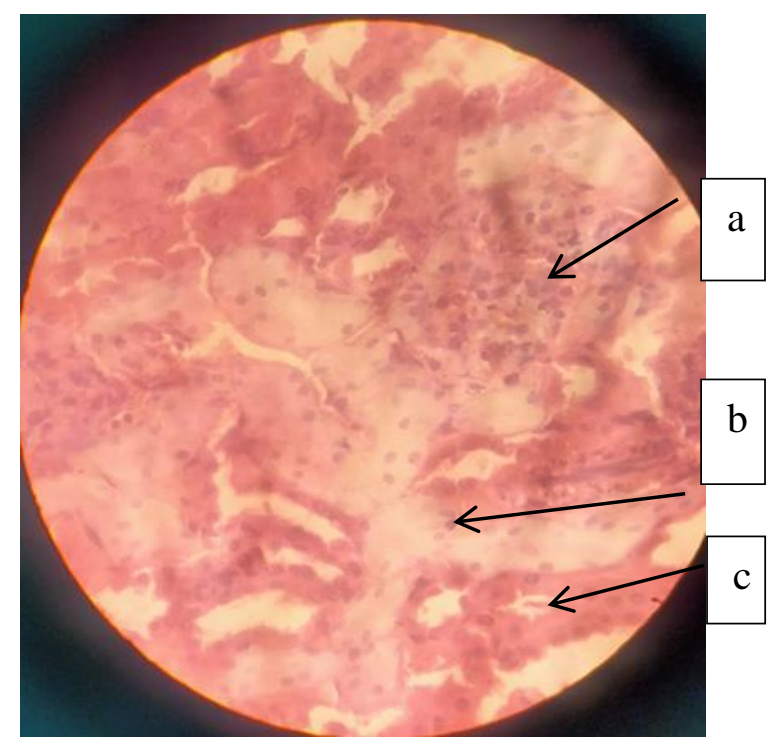

D. Control (-) DMBA treatment (K (-)) with 40x enlargement (HE). a. Necrosis, b. Degeneration, c. Inflammation

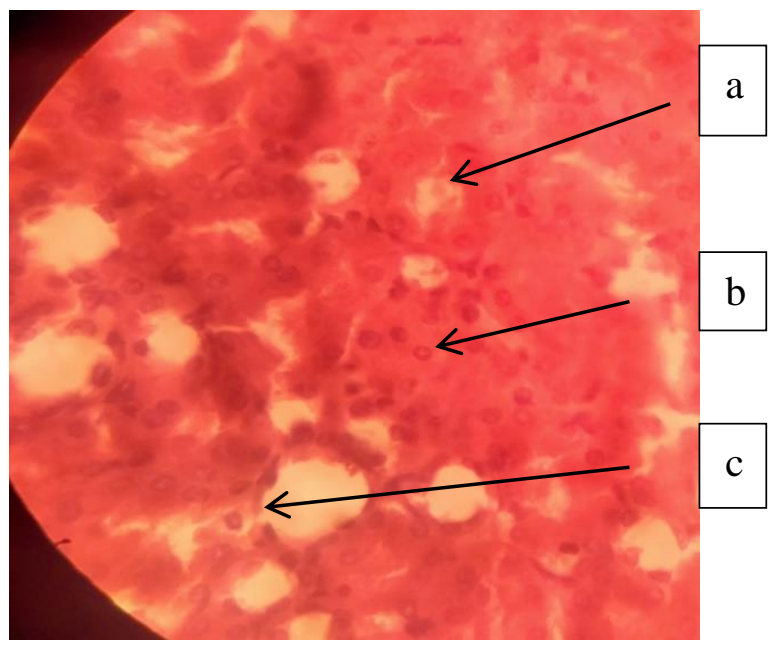

F. Treatment I (K-I) (200mg / kg BW). 40x (HE) magnification. a. Necrosis, b. Degeneration, c. Inflammation

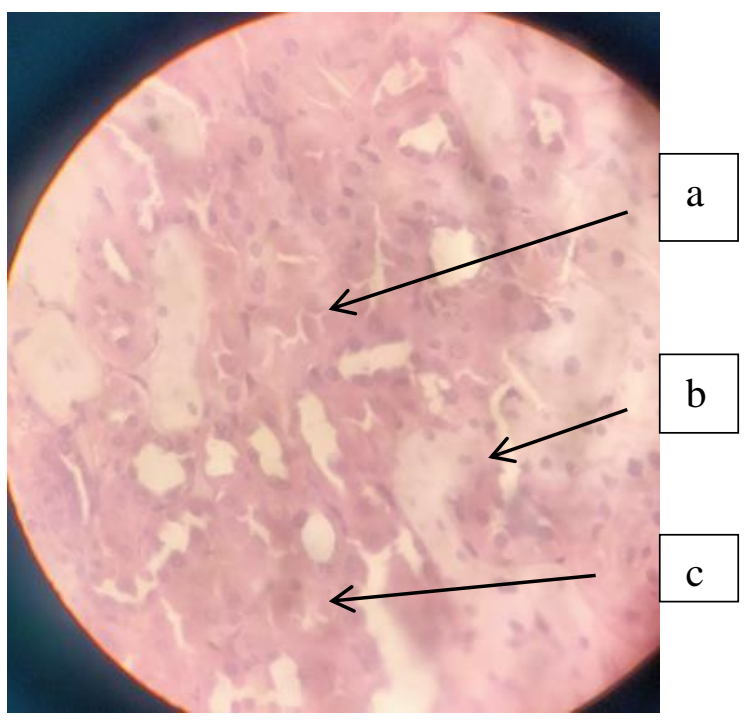


G. Treatment II (K-I) (300mg / kg BW). 10x magnification (HE).
H. Treatment II (K-I) (300mg / kg BW). 40x (HE) magnification. a. Necrosis, b. Degeneration, c. Inflammation

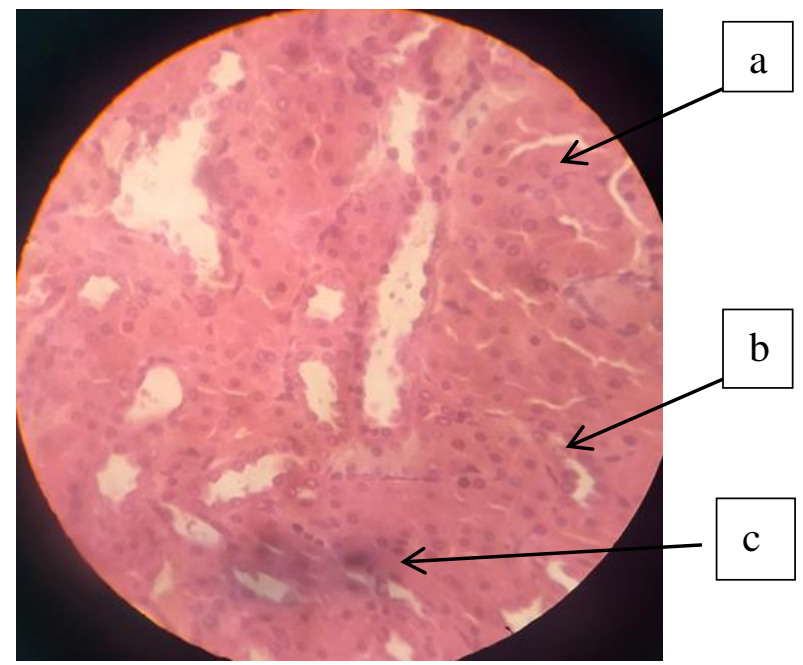

I. Treatment II (300mg / kg BW). 40x (HE) magnification.

a. Necrosis, b. Degeneration, c. Inflammation

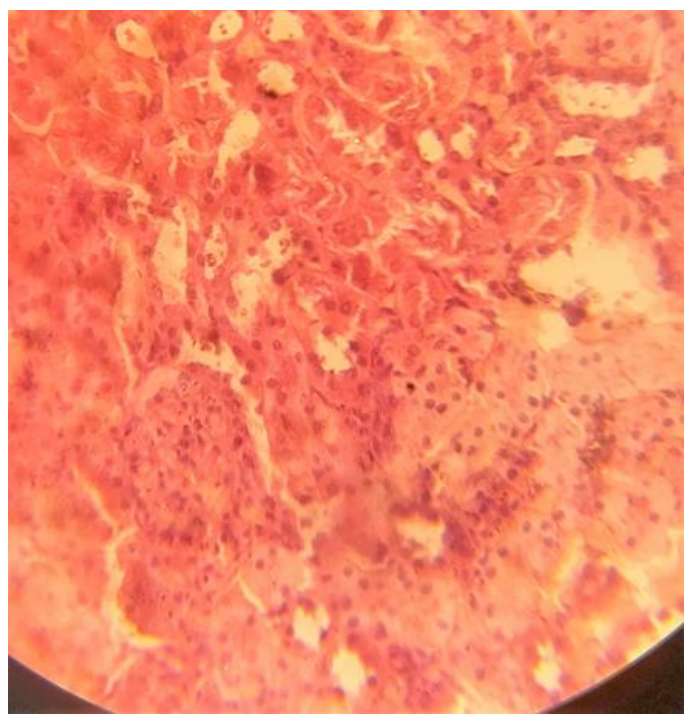

J. Treatment III (400mg / kg BW). 10x magnification (HE).

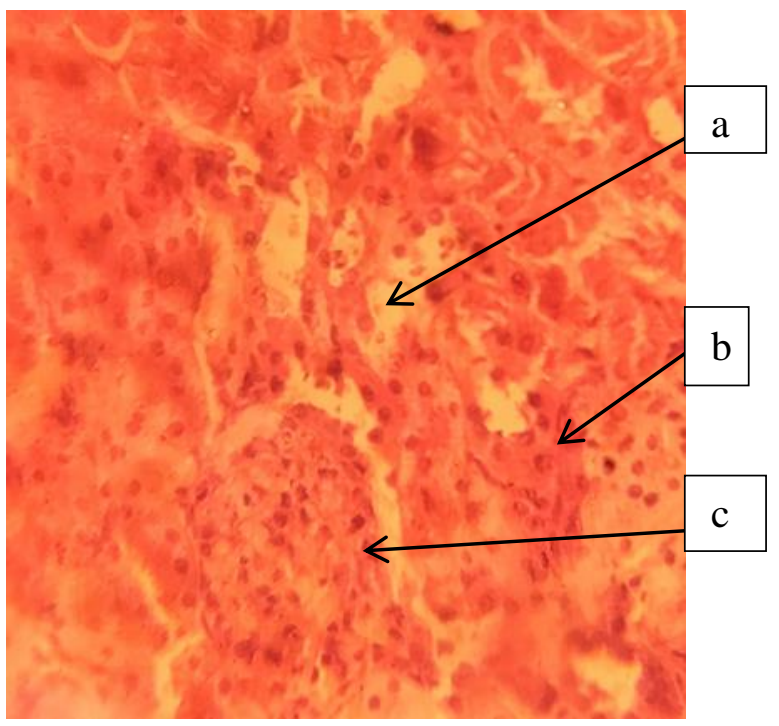

K. Treatment III (400mg / kg BW). 40x (HE) magnification. a. Necrosis, b. Degeneration, c. Inflammation 


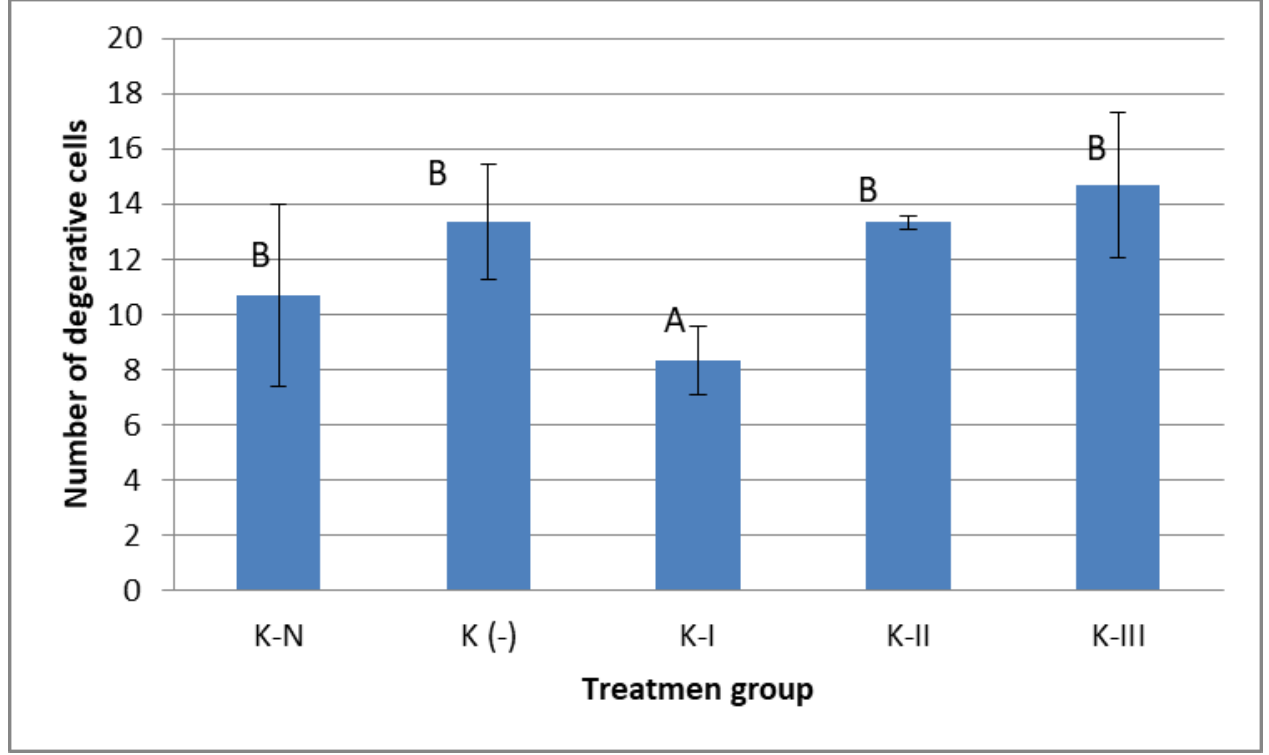

Fig 3. The number of kidney cells that have degenerated with One Way ANOVA

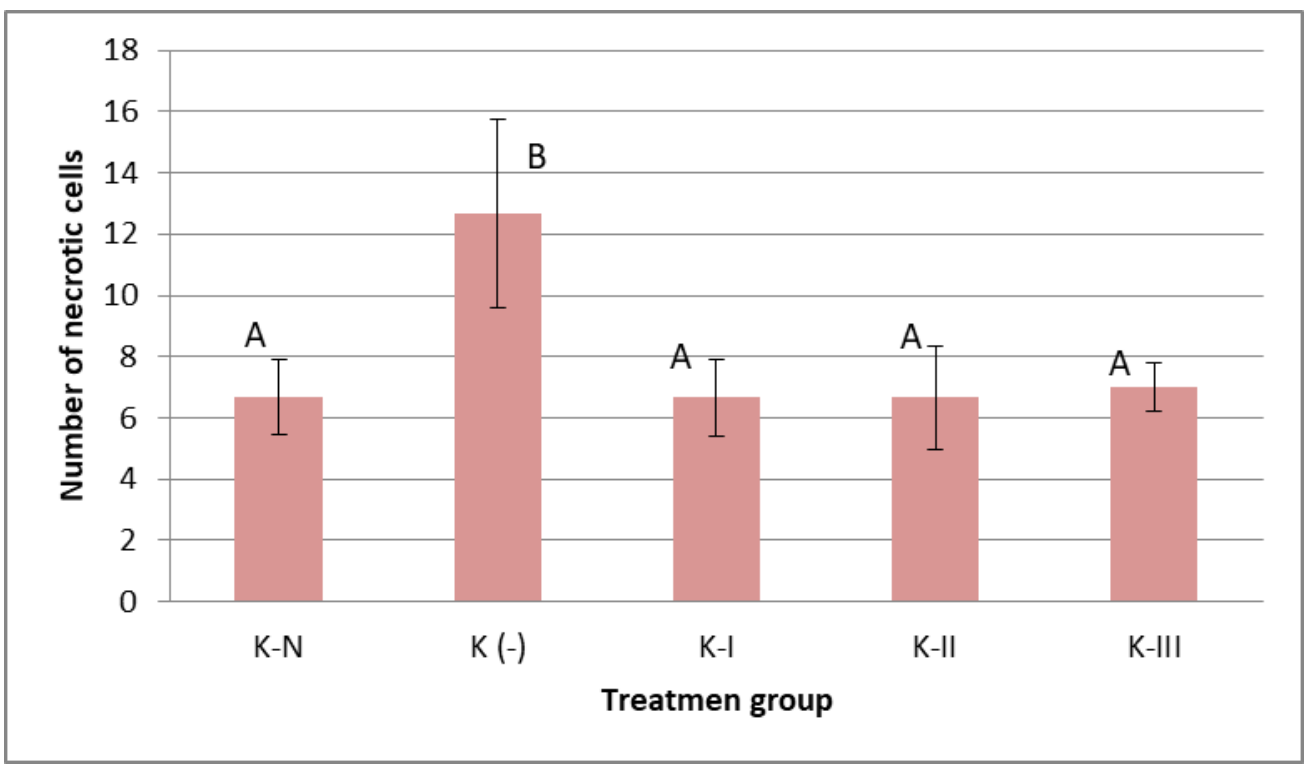

Fig 4. The number of necrotic cell on kidney with One Way ANOVA

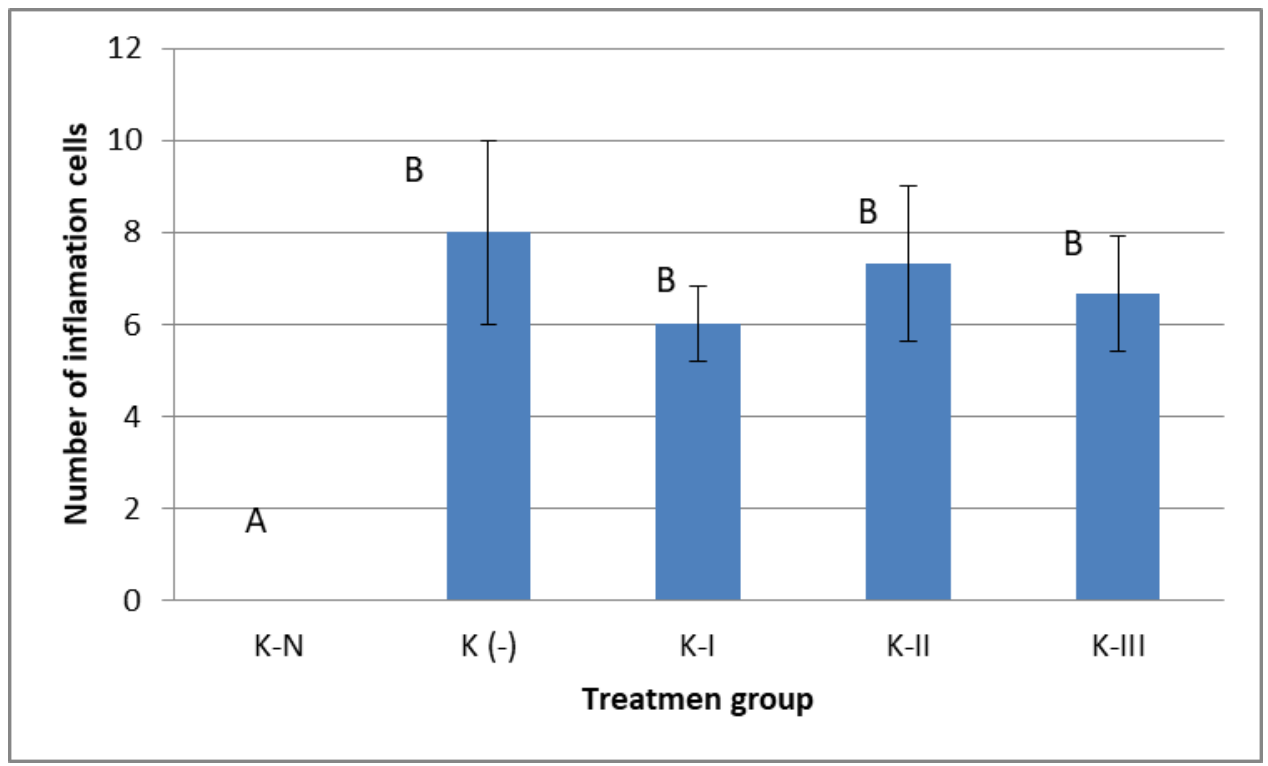

Fig 5. The number of cells that experience inflammation with One Way ANOVA 
In figure 3, 4 and 5, the negative control group shows higher degenerative damage, necrosis and inflammation than the other groups. This is due to the influence of DMBA carcinogens which can change normal tissue into cancer tissue through the free radical mechanism. DMBA is a carcinogen that can increase the level of cell necrosis so that cells die quickly. In treatment groups I, II, and III with the provision of S.trilobata leaf extract was able to decrease the level of necrosis.

The mechanism of carcinogenic DMBA occurs through metabolic activation (biotransformation). Metabolic pathway of DMBA by activation of the enzyme cytochrome P450 forms proximate carcinogens and ultimate carcinogens. Cytochrome P-450 and microsomal epoxide hydrolase $(\mathrm{mEH})$ metabolize DMBA into two metabolites, namely electrophilic metabolites and metabolites that are capable of forming DNA adducts (DNA that binds to carcinogenic compounds) [10] According to [11], S. trilobata has a chemopreventive effect on breast cancer with Rattus novergicus test animals which is strengthened by data on decreasing ALT and creatinine levels in $R$. novergicus induced by DMBA. [12] reported that secondary metabolites of flavonoids and steroids have the potential to prevent and treat cancer with high cytotoxic activity using the Brine Shrimp Lethality Test (BSLT) method.

Sphagneticola trilobata contains metabolite compounds such as flavonoids and steroids that have the potential to prevent and treat cancer [6]. The role of plant compounds as prevention and repair by preventing karsinogens from reaching the target location (initiation), inhibiting malignant transformation of cells during the promotion or progression phase so that the growth of proliferating cells is not controlled so that cancer cells will be inhibited from metastasizing. As for the way the prentive agent works by reversing, suppressing, preventing progression of cancer, one of which is by preventing the process of angiogenesis of tumor cells and the process of metastasis. Degeneration is a change in morphology and a decrease in organ function caused by fat accumulation and exposure to a chemical found in the cytoplasm, so that the cells appear edematous with clear and wide cavities. Under the microscope view, it appears that the cell nucleus is thinning and shrinking and its location is more towards the edge [13]. Necrosis is the loss of the cell membrane and the cytoplasm breaking down to form particles. Cell necrosis is characterized by a cytoplasm that appears more eucinophilic with accumulation of nuclear chromatin with a smaller, more basophilic nucleus. Necrosis is characterized by reduced color absorption by the nucleus and the release of tubular cells into the lumen. Inflammation in organs is a response from an organism that has been injured due to chemical compounds or other pathogens.Inflammation can be caused by infection in the organ or injury. According to research, acute inflammation is characterized by cells shrinking and clumping together [13].

\section{Conclusion}

The study concluded the optimum dosage of the extract S.trilobata which is able to inhibit the histo-logical damage of the kidney organs exposed to carcinogens DMBA is in the treatment I with a dose of $200 \mathrm{mg} / \mathrm{kgBW}$ with a decrease in the level of degeneration, necrosis and inflammation. The highest degeneration, necrosis and inflammation treatment was found in negative control.

\section{References}

[1] E. Costa et al., "A step forward in breast cancer research: From a natural-like experimental model to a preliminary photothermal approach," Int. J. Mol. Sci., vol. 21, no. 24, 2020, doi: 10.3390/ijms21249681.

[2] V. Mardina et al., "Preliminary phytochemical screening of different solvent extracts of flower and whole plant of Wedelia biflora," in IOP Conference Series: Materials Science and Engineering, 2020, vol. 725, no. 1, doi: 10.1088/1757-899X/725/1/012077.

[3] A. Manjamalai and B. Grace, "Chemotherapeutic effect of essential oil of Wedelia chinensis (Osbeck) on inducing apoptosis, suppressing angiogenesis and lung metastasis in V57BL/6 mice model," J. Cancer Sci. Ther., vol. 5, no. 7, 2013, doi: 10.4172/1948-5956.1000216.

[4] U. Venkatesh, C. Javarasetty, and S. K. Murari, "PURIFICATION AND FRACTIONAL ANALYSIS OF METHANOLIC EXTRACT OF WEDELIA TRILOBATA POSSESSING APOPTOTIC AND ANTI-LEUKEMIC ACTIVITY," African J. Tradit. Complement. Altern. Med. AJTCAM, vol. 14, no. 3, 2017, doi: 10.21010/ajtcam.v14i3.18.

[5] A. Teleman et al., "Altered Growth and Cell Walls in a of Arabidopsis Fucose-Deficient Mutant," Plant Physiol., 2012, doi: 10.1104/pp.110.160051.

[6] V. Mardina, S. Ilyas, T. Harmawan, H. Halimatussakdiah, and M. Tanjung, "Antioxidant and cytotoxic activities of the ethyl acetate extract of Sphagneticola trilobata (L.) J.F. Pruski on MCF-7 breast cancer cell," J. Adv. Pharm. Technol. Res., vol. 11, no. 3, 2020, doi: 10.4103/japtr.japtr_31_20.

[7] V. Mardina, S. Ilyas, T. Harmawan, H. Halimatussakdiah, and M. Tanjung, "Antioxidant and cytotoxic activities of the ethyl acetate extract of Sphagneticola trilobata (L.) J.F. Pruski on MCF-7 breast cancer cell," J. Adv. Pharm. Technol. Res., vol. 11, no. 3, 2020, doi: 10.4103/japtr.JAPTR3120.

[8] E. Meiyanto, S. Susilowati, S. Tasminatun, R. Murwanti, and Sugiyanto, "Efek kemopreventif ekstrak etanolik Gynura procumbens ( Lour ), Merr pada karsinogenesis kanker payudara tikus,” Maj. Farm. Indones., vol. 18, no. 3, 2007.

[9] A. Suchantabud, C. Talubmook, S. Chomko, and N. Narkkong, "Hematological Values and Ultrastructure of Blood Cells in Piper sarmentosum Roxb. and Tinospora crispa Miers ex Hook. F \& Thoms. Treated Diabetic Rats," J. Microsc. Soc. Thail., vol. 22, 2008.

[10] M. E. Inanç et al., "The effect of green tea extract supplementation in bull semen cryopreservation," Kafkas Univ. Vet. Fak. Derg., vol. 25, no. 5, 2019, doi: 10.9775/kvfd.2019.21702.

[11] E. Safarzadeh, S. S. Shotorbani, and B. Baradaran, "Herbal medicine as inducers of apoptosis in cancer treatment," Advanced Pharmaceutical Bulletin, vol. 4, no. SUPPL.1. 2014, doi: 10.5681/apb.2014.062.

[12] H. A. Adinugraha and N. K. Kartikawati, "Variasi Morfologi dan Kandungan Gizi Buah Sukun," Wana Benih, 
2012.

[13] "26. GAMBARAN HISTOPATOLOGIS GINJAL TIKUS PUTIH (Rattus novergicus) JANTAN YANG DIINFEKSIKAN Trypanosoma evansi DAN DIBERI EKSTRAK DAUN SERNAI (Wedelia biflora) (Histopathology of Male Rat (Rattus novergicus) Kidney Infected with Trypanosoma evansi and Treated with Sernai Leaves Extract (Wedelia biflora)),” J. Med. Vet., vol. 10, no. 2, 2016, doi: 10.21157/j.med.vet..v10i2.4386. 